\title{
ChILdHOOd IN EXILE:
}

\section{The Agency of Second-Generation Exiles SeEking Refuge from Apartheid}

\author{
Zosa Olenka De Sas Kropiwnicki
}

\begin{abstract}
This paper is based on a retrospective study of children who were born in exile and/or spent their formative years in exile during apartheid. It is based on 21 in-depth interviews with men and women who spent their childhoods in an average of three different countries in North America, Western Europe, the Nordic region, Eastern Europe, West Africa, and East Africa as second-generation exiles during apartheid. This article will argue that the interplay of structure and agency in the lives of second-generation exiles in the process of migration and in the transitory spaces that they occupied should be explored. Secondgeneration exile children devised a range of strategies in order to challenge or cope with constantly shifting contexts characterized by inequalities, social exclusion, violence, and political uncertainty.
\end{abstract}

\section{Résumé}

Cet article s'appuie sur une étude rétrospective d'enfants nés en exil ou qui ont passé leurs premières années en exil durant l'apartheid. L'étude est basée sur 21 entrevues en profondeur avec des hommes et des femmes qui ont passé leur enfance comme des exilés de deuxième génération au cours de l'apartheid dans une moyenne de trois pays différents en Amérique du Nord, Europe occidentale, région nordique, Europe de l'Est, Afrique de l'Ouest et Afrique de l'Est. Cet article fait valoir que l'interaction de la structure et de l'entremise dans la vie des exilés de seconde génération en voie de migration et dans les espaces transitoires qu'ils occupaient devrait être explorée. Les enfants exilés de deuxième génération ont mis au point une gamme de stratégies en vue de contester ou d'affronter des contextes en constante mutation, caractérisé par des inégalités, l'exclusion sociale, la violence et l'incertitude politique.

\section{Introduction}

Between 30,000 and 60,000 people-adults and childrenwent into exile during apartheid following the banning of opposition political organizations such as the African National Congress (ANC) and Pan African Congress (PAC), and the initiation of the armed struggle in 1961. In addition to participating in strategic planning, military training, and armed combat, exiles established dwellings all over the world. They constructed "homes," engaged in intimate relationships, and raised children. The literature tends to focus narrowly on strategic military operations and largely ignores the politics of the everyday where individuals negotiated power dynamics and waged "strategies of resistance"1 in their new environments in exile.

Efforts have been made to elucidate the gendered dimensions of these struggles; ${ }^{2}$ however, children's voices have remained on the periphery of academic enquiry. The agency of children growing up in exile is poorly described. They appear as invisible actors or silent bystanders-their intentional decision-making ${ }^{3}$ and transformative action on the structures in which they were "bounded" remains unrecognized. Second-generation exiles, who were born and/or spent their formative years in exile, were described as passively being acted upon by their parents and teachers, or as "sponges" simply absorbing the dominant political 
ideology-effectively denying them agency and power. There is little information about the manner in which children negotiated power relationships, waged everyday acts of resistance, or shaped their environments.

\section{Literature Review}

Exile as Strategic Space

Exile tends to be defined as physical "banishment" and geographical dislocation impelled by a political regime intent on preventing social change. ${ }^{5}$ Exile in this study has been conceptualized not in relation to geographical place but to a historically specific "condition" 6 or process ${ }^{7}$ associated with forced estrangement from a lived or imagined home in the context of political struggles against "norms of a nation."8

It is increasingly argued that the exile experience cannot be reduced to "militaristic, top down and bureaucratic"9 power relations, and "narrow military and strategic objectives," 10 as this obscures the diversity of experience and the extent to which "strategies of struggle"11 are played out in a range of social relationships, all diffused with power, as argued by Foucault. A number of exile studies in a range of social science disciplines (such as political science, sociology, and historical studies) have tried to explore this complexity, such as in relation to gender, ${ }^{12}$ marriage, ${ }^{13}$ sexual relationships, ${ }^{14}$ families, ${ }^{15}$ social networks, ${ }^{16}$ and "daily life in the camps." ${ }^{17}$ However, the strategies waged by children in exile remain largely unexamined, particularly in relation to second-generation exiles.

\section{Children and Difference}

Studies that refer to second-generation exiles fail to acknowledge the diverse manner in which childhood is constructed and experienced. ${ }^{18}$ This stems from an underlying essentialist approach to exile identity and experience, which fails to account for the complex manner in which socially constructed social divisions "intersect."19 Clifford argues that diaspora theories need to account for racialized, classed, and gendered structures, ${ }^{20}$ but does not mention structures pertaining to generation.

Bernstein and Manghezi provide an uncritical presentation of the voices of ANC leadership's children. ${ }^{21}$ Apart from passing reference to children of mixed nationality at Solomon Mahlangu Freedom College (SOMAFCO), ${ }^{22}$ Morrow and colleagues do not adequately illustrate the diversity of children living in Morogoro, ${ }^{23}$ Tanzania. Authors have provided superficial analysis of markers of difference, including birth in exile, ${ }^{24}$ race, ${ }^{25}$ and gender. ${ }^{26}$ Literature referring to second-generation exiles tends to focus on the former frontier states, ${ }^{27}$ Tanzania, ${ }^{28}$ and the United Kingdom; ${ }^{29}$ however, this does not elucidate the manner in which childhood was constructed or experienced elsewhere.
Children as Invisible Actors and Silent Bystanders

Said states that "exile is not, after all, a matter of choice: you are born into it, or it happens to you." 30 However, he does confer an element of agency on "the exile." Clifford argues that exiles do not simply acquiesce in a linear model of integration, acculturation, and assimilation, but actively interpret, negotiate, and influence their circumstances by drawing upon "skills of survival" 31 at an individual and collective level.

The literature on children in exile tends to focus on their role as bearers of "post-memory," because they "grow up dominated by narratives that preceded their birth." 32 Alternatively, children are described as targets for the transmission of collective identity and cultural practices. ${ }^{33}$ These studies refer to clashes in notions of filial duty and children's search for their roots; ${ }^{34}$ however, they do not fully acknowledge children's agentic engagement with the exile experience. ${ }^{35}$

Unlike school children who intentionally joined Umkhonto we Sizwe (MK) in the wake of the Soweto school boycotts in 1976 and who-according to official accounts-matured on the battleground into "youth,"36 second-generation exiles were denied agency, as epitomized in Bernstein's statement: "Children had no choice, they were either taken or left behind, but played no part in the decision." 37 Numerous accounts refer to cadres falling pregnant or bearing children in exile, yet there is little information about second-generation exiles' experiences in the exile context.

Although a number of texts refer to the services children received in exile, ${ }^{38}$ these authors paint an uncritical picture of the lived realities of children. Children's agency, perspectives, and opinions are absent in these texts. Similarly, various texts refer to their political socialization, such as through the Young Pioneers children's club, ${ }^{39}$ but these accounts simply describe children as passive recipients of political ideology, without discussing the children's (re) interpretation or contestation of these notions.

In the above accounts, children's agency appears to play out only in terms of "anger and resentment" towards their parents. ${ }^{40}$ However, there is little understanding of the manner in which parenthood is constructed in exile ${ }^{41}$ or how children navigate other significant relationships, such as with their siblings, many of whom were left behind in South Africa or in camps; ${ }^{42}$ their grandparents, many of whom became surrogate parents; ${ }^{43}$ their peers; and other adults often described as "aunts" and "uncles."44 Various accounts in Ngcobo's collection of life stories describe children's struggles to develop friendships in the face of racism. ${ }^{45}$ However, these stories paint a picture of victimization, "loss and bewilderment," ${ }^{6}$ without acknowledging 
children's minor acts of resistance or what Scott described as "ordinary weapons of the weak." 47

\section{Bounded Agency as Intentionality}

At a theoretical level, this article will refer to children's agency as "bounded." 48 Through the interplay of meanings, norms, and power, the social structure both constrains and enables human agency by affecting agents' aspirations, self-esteem, personal standards, affective states, and selfregulatory standards. ${ }^{49}$ In everyday action and interaction with other actors, individuals both entrench and transform this social structure, ${ }^{50}$ whose actions and development the structure in turn influences. ${ }^{51}$

Intentionality is central to agency. Foucault argues that one must account for the "aim of the struggle to overcome the effect of power." 52 Bandura argues that even children have the capacity to act with intentionality-exhibiting selfefficacy, forethought, and self-evaluation-on their own, by proxy through someone, or collectively with others. ${ }^{53}$ They may draw upon individual or interpersonal resources to negotiate their positions in relationships, ${ }^{54}$ fight against injustice, and attempt to circumvent the power of others, in what Foucault describes as "strategies of struggle." 55 Their strategies may involve evasion, humour, gossip, moral reasoning, manipulation, passive resistance, and open contestation, 56 "although such tactics are rarely recognised by adults." 57

The bounded nature of children's agency and the strategies that they developed in exile will be explored in this article. The respondents presented a combination of experiences of feeling "done to," alongside expressions of agency"doing" and "transforming."

\section{Methodology}

This research sought to understand the manner in which childhood was constructed and experienced in exile communities during apartheid and upon return to South Africa. Secondary and primary data were collected in this study. Secondary sources included academic books and accredited journal articles, as well as autobiographies, biographies, and newspaper articles.

As there is no central database or list of second-generation exiles, systematic or random sampling approaches were not utilized. Instead, snowballing (chain-referral) was used to identify "hidden" populations who met the following criteria: they were born and/or spent their formative years $(0-18)$ in exile during apartheid, and they were residing in South Africa at the time of the fieldwork. In this exploratory study, 21 respondents were identified and interviewed using a word-of-mouth snowballing technique. As this sampling technique depends on social networks, it introduces a level of bias. ${ }^{58}$ All attempts were made to reduce these biases by posting recruitment announcements on a range of mailing lists and websites (e.g., the H-SAFrica discussion forum). This may have introduced a self-selection bias but widened the pool of respondents and created new points of access. Although this study is not representative, it offers detailed insight into the experiences and understanding of respondents, whose voices and attempts to exercise power tend to be ignored. ${ }^{59}$

A life history approach was used to gather data, enabling respondents to focus on events, places, and relationships that are significant to them. Non-directive questions were then asked as triggers to open further discussion over a twoto three-hour period. With the permission of respondents, the interviews were audio recorded digitally. Transcripts were sent to the respondents, which allowed them to reflect on their responses, verify the data, or raise concerns. Apart from minor cases involving the spelling of names and places, no significant revisions were requested by the respondents. The data were analysed thematically and manually using Microsoft Word; open-coding was used to categorize and examine themes and patterns. ${ }^{60}$ This study used a theoretically and methodologically reflexive approach, which was documented in a field diary ${ }^{61}$

The study adhered to the ethical standards promoted by the Oral History Association of South Africa (OHASA) Code of Conduct. ${ }^{62}$ Ethical data collection and management included obtaining informed written consent; offering the right to withdraw or seal a transcript; confidentiality; anonymity and protected storage of data. Identifiable information has been obscured in the particle as a result of the political sensitivity and safety concerns raised by the respondents. Although a life history may produce "great relief and release,"63 it might inadvertently lead to "pain caused by remembering difficult memories." ${ }^{\prime 4}$ At the outset of the interview, respondents were provided with contact information for qualified counsellors at the University of Johannesburg, although no respondents utilized this service.

The sample (21) characteristics are as follows: 7 (33\%) were male and $14(67 \%)$ were female. Seventeen $(80 \%)$ were black, $2(10 \%)$ were white, and $2(10 \%)$ were Indian. At the time of the interviews, $3(14 \%)$ were younger than 30 years of age, $8(38 \%)$ were between the ages of 31 and 35 years, 7 (33\%) were aged 36 to 40 years, and 3 (14\%) were older than 41 years.

The age at which the respondents went into exile is as follows: 9 (43\%) were born in exile, 9 (43\%) were aged 1 to 5 years, and $3(14 \%)$ were older than 6 years. Three (14\%) returned to South Africa from exile aged 0 to 10 years, 11 $(52 \%)$ were aged 11 to 18 years, and $7(33 \%)$ were 19 years 
or older. When in exile, the respondents lived in a number of different countries: 6 (29\%) stayed in 1 country, 4 (19\%) lived in 2 countries, 9 (43\%) lived in 3 countries, and 2 (10\%) lived in 4 countries. With this in mind, the respondents listed 47 countries in 6 regions in which they lived in exile: 16 (34\%) lived in southern Africa, 9 (19\%) lived in Eastern Africa, 1 (2\%) lived in West Africa, 10 (21\%) lived in Europe, $6(13 \%)$ lived in the United Kingdom, and $11 \%$ lived in North America. ${ }^{65}$ The majority of the respondents' parents either had refugee status or study permits. ${ }^{66}$

\section{Limitations of Retrospective Interviews}

Many academics have questioned the validity of memories as a source of data. As "an artefact that rusts," 67 memories may distort or fade. ${ }^{68}$ Others have pointed to temporal continuity, as the past experience of exile informs identity in the present, and the present informs what is "remembered" and narrated about exile. ${ }^{69}$ Said argues that for exiles, experiences in new environments occur "contrapuntally"70 with memories of experiences in old environments. The narration of these memories is informed by present needs. ${ }^{71}$ The process of recollection and narration may help exiles depict themselves in a particular way, place themselves in the "starring role,"72 "reconstitute their broken lives,"73 find content to notions of "home" and "belonging,"74 and/or craft and re-craft their identities in the present. ${ }^{75}$ Memories may be selectively recovered, reshaped, and reinterpreted at a collective level under the influence of dominant discourses, political frameworks, and memoralization efforts. ${ }^{76}$ Therefore, some academics argue that memories-and narration as the vehicle through which memories are shareddo not necessarily produce a truthful, "authentic" view of the past. ${ }^{77}$

During the course of the interviews, respondents questioned the "quality" of their early memories, particularly since many went into exile, over 20 years ago. Furthermore, some respondents reflected on their use of adult terms, emotions, and reference points when describing their childhoods. In this article, many quotes reveal the tension between children's perceptions and feelings in relation to particular events and behaviour, which are recalled and narrated by adults, juxtaposed against adult reinterpretations, or rationalized in hindsight. Further, the respondents positioning and experiences in post-apartheid South Africa are likely to have influenced their selection and narration of particular memories of exile.

Notwithstanding these considerations, the narration of memories of exile provides opportunities for reflection for the respondent and researcher. ${ }^{78}$ Some argue that narration provides partial versions and experiences, which, when viewed in relation to each other, lend credence to the
Foucauldian notion that truth is a "thing of this world."79 However, it needs to be noted that the objective of this study was not to provide a historical realist version of the "truth" but to present different perspectives of lived experiences. Narration also "gives voice" to those who have been marginalized, or, as has been argued in the South African context, as the "ritualistic lifting of the veil" 80 or the gluing together of "cracked heirlooms" 81 that represent the multiplicity of hidden voices, which were silenced by apartheid.

\section{Findings}

Childhood was constructed differently, depending on where the children came from and where they travelled through, to, or settled. The family, playground, and schoolroom were described as "political spaces" fraught with battles over gender, ethnicity, socio-economic status, and political ideology. It will be argued that as agents, their decisionmaking and action was influenced by social structures at the level of the interpersonal, but through their action some tried to resist or transform these structures. Their responses reveal a combination of feelings related to being "done to" and "doing."

\section{Constructions of Parenthood in Politicized Settings}

In this politicized context, intergenerational communication was shrouded in secrecy and silence. Many of the respondents complained that their parents never explained why they were in exile. Some attributed this to the African culture where "there is no real need to explain to a six-yearold why the world is the way it is," 82 and "when adults came, you just had to disappear." 83 One respondent stated that he is still "mad at them" 84 for never explaining apartheid. Some respondents explained that these silences were deliberate in order to protect them, which meant that it felt like "an adventure" 85 rather than an escape from violence. Many understood this in retrospect, but at the time they felt "cut off" 86 and excluded from their parents. Some respondents stated that even when their parents tried to explain the situation to them, they simply were too young to understand: "I knew who Nelson Mandela was always and I used to draw little pictures to send to him, [but] I didn't have the vocabulary to understand what they were talking about." 87

Parental absences were also a factor of exile, which were rarely explained to children: "Like when he went away he never told us where he was going, though he was silly because he would insist that my mother packed his case, so you could sort of figure it out: Angola or the Soviet Union. But we never knew how long he was going for." 88 For some this was simply a "normal state of affairs." ${ }^{89}$ For others this was a source of pain and frustration, particularly when significant events were missed. 
Some respondents rationalized these absences by referring to a choice that their parents had to make: politics or parenthood. For instance, one respondent who was placed in boarding school when she was a toddler said that in her family "we [the children] weren't a priority." 90 Her mother worked long hours, while her father engaged in political activities. She recalled her parents forgetting to collect her at school and then enviously watching other children interact with their parents: "I remember sitting there and thinking, why didn't my parents do that with me?"91

Some parents were forced to leave one child behind in South Africa or in a camp. This had profound effects on sibling relationships. One respondent recalled having to lie to his youngest sister about the impending trip, but also secretly fearing that he would be left behind: "I didn't sleep the night before. It was a secret from the one after me, and I was worried that it would happen to me too and they would leave me behind." 92 Children themselves had little say in this type of situation; however, one respondent exercised his agency by fabricating stories of physical abuse at the hands of relatives so that he would not be left behind. ${ }^{93}$

In contrast, some parents insisted on remaining with their children, even if it meant taking them on training and missions. A respondent recalled being taken on one such mission: "It was great going to Swaziland for me because there were sweets and chocolates. But my brother got really scared because he knew what we were doing. He used to throw up the night before we left for Swaziland." 94 This respondent also described a moment when her mother-upon receiving a notification to send her children to Tanzania-locked herself in the bathroom until they were allowed to stay. She attributed this success to racial and socio-economic differences: "It was one of the times I noticed the difference between being middle class and white. We had a choice. We could go to the UK. Other moms didn't have a choice: they had nowhere else to go, they had no family, and they had no support. And if you speak to kids who were sent to SOMAFCO, there is a lot of resentment that they were sent away."95

Discipline was another factor of childhood in exile. A number of respondents referred to a "culture clash" associated with the "unquestioned obedience that children owe their parents in Africa." 96 This manifested itself in strict parenting, corporal punishment, and efforts to curtail their freedom. This was very acute for children in exile whose friends experienced a different kind of freedom in North America: "My parents were stricter than other American parents. I was beaten a lot more than them; it wasn't child abuse, it was just what we do. I complained to my parents but they said I can't compare myself with other children because I was from different circumstances." 97
Many of the respondents described their attempts at exercising agency and struggling for freedom. Some referred to verbal arguments with their parents, slamming doors, and leaving angry notes. A respondent referred to anger at her mother's refusal to permit her to sleep over at friend's homes in Canada: "Sleeping over wasn't an African thing ... It was a massive source of tension. She couldn't control it and didn't know what we were being exposed to." 98

Rebellion was also a form of agency. Some respondents engaged in "risky activities" such as petty theft, alcohol consumption, and drug abuse, as a means of exercising their agency. A respondent was very frustrated at his parents for putting everyone else's needs above his own: "I would speak back, I was a brat. I had no control. I had an opinion for everything. I fought with the system." 99 As a result, he was expelled from three schools in Zimbabwe. These are not unusual challenges for immigrant populations to experience, but in the case of second-generation exile children, these tensions in the home were exacerbated by other difficulties such as the frequent absence of parents who were on mission or undergoing training.

Respondents drew on inner resources when trying to cope with these interpersonal problems. One respondent coped with his father's drinking and emotional distance by spending hours reading on his own and, for the most part, relying on himself. Another stated that she coped with being placed in a boarding school from a young age by constructing a fantasy world: "I used to write stories in my head. I would live in my head how I wanted it to be. I just escaped." 100 Another respondent coped with the secrecy required of living underground with her mother by fabricating the truth about her life-beyond what was required of her: "So now I was allowed to lie, so I went the whole hog and it allowed me to be the person I wanted to be." This included constructing a fantasy of living in her grandparent's tree house. ${ }^{101}$ As children, some respondents found solace-and a voice of protest-in their artwork, poetry, and diaries. These agentic strategies should, therefore, not be ignored.

\section{Political Socialization}

Second-generation exiles were socialized directly and indirectly into political awareness. Some recalled eavesdropping on their parents during political meetings: "When I was very small, we used to hide behind the sofa when he was having these meetings. And I think we just wanted proximity to him. And then we would get all silly like kids do and start shoving each other, and he would kick us out."102 There were, however, deliberate attempts by their parents to inculcate a particular set of values, vision, and understanding of politics. 
Some parents gave their children books to read about South Africa. Others named their children after political leaders. Some took their children to anti-apartheid demonstrations or ANC meetings. A child recalled handing out T-shirts, stickers, and pamphlets at one such event in Spain. Another recalled the overwhelming feeling that "everyone is there for a common purpose" at rallies in the United Kingdom. ${ }^{103}$ June $16^{104}$ was a "public holiday" for second-generation exiles scattered across the world. A respondent recalled her sister trying to copy her father's flyers by drawing "pictures of the national liberation struggle with cute bunny rabbits on them."105 Another respondent reflected on the toys that they were given in exile: "When we were in Zimbabwe, my father used to go and buy us toy guns ... I think at the time they thought these children have to be socialized because they will have to take up the struggle."106

Respondents who spent a portion of their childhoods in the frontier states and at SOMAFCO spoke about the politically charged environment, characterized by Friday news readings, political songs, slogans, and "performances" such as the symbolic burning of coffins representing apartheid leaders. Many children did not understand these messages: "There was a Zulu song that the lines went 'We are going to wake up at four in the morning and going to go revolt.' I knew what revolt meant, but in terms of the bigger picture, I don't think I really understood that."107 ANC children attended the Young Pioneers in Mozambique, Zambia, and Zimbabwe where they engaged in "political play" activities on weekends.

Political socialization was also associated with fear of political threats. A respondent recalled feeling "very embarrassed" when the ANC bomb squad detonated an envelope containing a school photograph, which she had failed to inform her parents about. She also recalled her father using code language because he was concerned that she would "blurt things out innocently."108 Another recalled feeling scared and unsettled when trenches were constructed at SOMAFCO. Fears of infiltrations and spies meant that the children had to be careful of speaking to strangers and other South Africans, and these threats were not always unfounded. For instance, in the United Kingdom, a respondent's home was destroyed by a bomb, and she regularly noticed spies lingering on her street. A respondent in Mozambique stated that she had to walk a different route to school every day and had to stand back when the car ignition was turned, in case there was a bomb in the vehicle. ${ }^{109}$

Political socialization was also associated with the death of a close relative, which heightened the political sensitivity of children. The murder of one child's stepfather in
Swaziland precipitated the family's move to the United Kingdom. Another recalled the loss of his mother: "I remember feeling lonely a lot of the time, and I kept believing that when we moved we would meet up with my mother. And we moved a lot, so there was this continuous feeling of disappointment." 110 A respondent's brother was killed in a bomb that was intended for his parents; he was too young to understand what happened, but knew that his brother was "not coming back." He described how his mother became extremely over-protective: "We weren't allowed to go anywhere or see anyone."111

Many of the respondents referred to their homes as being used as safe houses for exiles passing through on their way out of South Africa, or en route to training or military missions. As one respondent stated, "When I think of memories of home, politics was always there. There were always people sleeping at our house."112 For some children, this was an important time in their political socialization, filled with important discussion and new acquaintances, but this also was a source of tension. As one respondent stated, "I don't think I minded, until I was chucked out of my room, and this happened often."113 This was echoed by another respondent: "There were a lot of things that started to annoy me when I got older. Like when adults come to your house and you have to give up your bed and you have sleep on the floor in the living room. If you leave stuff in the fridge and then the next day it tended not to be there. I was teenager: what is mine is mine. And I also felt like my parents were not my own. And I think that is a very painful thing, when you know you have to share your parents."114

Children reacted to political socialization in different ways. One respondent described the expectation that he had to contribute to his community as a "burden." $115 \mathrm{He}$ didn't understand what the rallies were about and why he had to spend 16 June 16 with his parents, when all he wanted to do was play with his friends. He stated, "I think there was plenty of resistance. You feel your parents are pushing you in a direction you don't want to go in. Why don't other kids have these problems? Why is it that other kids don't have to go to a soup kitchen and serve? Why is it that other kids don't have to deal with all this stuff? I looked at it and thought, 'Stuff this, I am going to act like other kids,' and I remember I got the biggest spanking."116

Another respondent stated that he made a deliberate show of not being interested in the books or news items related to South Africa: "My attitude was very much 'No, this is not me. I am somebody very different, and this is an alien and frightening country, which is responsible for destroying our family, and I don't want to get engaged with it."'117 Some deliberately tried to distance themselves from any association with the exile movement in order to "fit in." 
"You don't know what people's views are, so being a bit cautious about what you were saying. I told one friend that my dad was a communist, and she said her dad hated communists and wanted to kill them all. Then I realized I shouldn't have said anything."118 Others exercised their agency by actively fighting against racism and xenophobia in their host communities.

\section{Racism and Xenophobia}

Many respondents were the targets of racism and xenophobia in North America, Western Europe, and in the Nordic countries. People treated them as a "curiosity,"119 while others were "openly hostile." ${ }^{20}$ One respondent's father tried to explain, "'Don't feel bad, this country [USA] is crazy and this country is not nice, it has nothing to do with you. You are black, you are female, and you are an immigrant. All three of those things don't belong in this place."'121

Another respondent stated that the racism made her feel uncomfortable: "It made me question why people hate us because of our skin colour. My sister even asked my parents when we are going to be white."122 Language differences were often used as a proxy for structural and interpersonal racism, to the extent that people-adults and childrenwould criticize their language skills and/or "talk down to them in a way that made [them] feel stupid." 123 This had a significant effect on peer relationships. One respondent referred to the racist "undercurrent" in the playground. ${ }^{124}$ Another respondent referred to the "playground as a political space" characterized by racial clashes. She recalled crying after a child asked whether she eats spaghetti with her fingers or soup with a fork and knife. ${ }^{125}$

Even within SOMAFCO and the frontier communities there were racist prejudices. An Indian girl recalls her birthday when black children refused to play with her. Another respondent described games where she was always given the role of the "baddy" because she was white. ${ }^{126}$ Some children spoke of the "othering" of white children who accompanied their European parents to volunteer at SOMAFCO. ${ }^{127}$ There was also racism in relation to indigenous people. The children called the local village close to SOMAFCO the "dark city," into which they rarely ventured. ${ }^{128}$

Some respondents exercised their agency by intentionally trying to challenge racist practices. For instance, one respondent insisted that her history teacher give a lesson on apartheid. She also adopted the "punk rock" culture in the UK as a means of expressing her fight against fascism and racism. ${ }^{129}$ Some respondents organized protests against racism in North American schools. One respondent stated that her teachers didn't like her because she was always "questioning" the treatment of black children. ${ }^{130}$ Another respondent refused to return to school in Denmark when racist books were not removed from the library. ${ }^{131}$

In the face of racism and xenophobia, the respondents tried to overcome their loneliness by intentionally devising a range of strategies to cultivate friendships. In Bulgaria, for instance, a respondent desperately tried to "learn the culture and mannerisms." 132 Some respondents forged close friendships with other children who seemed to be coping with similar issues of death, loss, and dislocation. Many children forged friendships with children from other minority groups. For instance, a respondent stated that she befriended an Indian girl and a Columbian girl, and "we were the only people of colour in that crèche." ${ }^{33}$ On the other hand, one respondent described her attempts to look and speak like a white Canadian person, including trying to change her accent, straighten her hair, and wear particular clothing brands. ${ }^{134}$ Others deliberately forged relationships with adults in the community-whom they described as "aunts" and "uncles"- as a substitute extended family.

Unfortunately, developing and investing in relationships also had unintended consequences, such as a recurrent sense of loss associated with frequent migration. Many respondents said that they learnt strategically how to compartmentalize relationships so that it was easier to say goodbye. A respondent described this as her "defence mechanism": "When you are gone, you are gone. Keeping in touch is not important." 135

\section{Socio-economic Status}

There were contrasts in the socio-economic status of exile families, depending on where they went into exile and their political standing. On arrival in exile in North America and Western Europe, many respondents moved into slums with other foreign nationals and referred to everyday socioeconomic challenges faced by their parents when trying to put a meal on the table or purchase sanitary wear for girls. However, there were also significant differences when comparing exile communities in Europe to Africa. When relocating from Denmark to Tanzania, one respondent stated that she was "shocked" at the food that they were expected to eat: "It was all strange for me, coming from a developed country to an ANC camp where we had to go to this warehouse to get our rations every month."136

Socio-economic status was a relational concept, and constant comparisons were made within exile communities. Some exile families who were associated with the ANC leadership and strategic wing were able to afford live-in nannies, private schools, and new clothing. A child living in Zimbabwe noted the salience of socio-economic differences within the exile community-epitomized for her by the school bus that would collect the poorer children 
from government schools, followed by another bus for the wealthier exile children at private schools: "You know, in exile there was this thing of families who were just better than the rest, the big names. That's how the ANC worked, so you knew that they deserved more than the rest of us." 137 It was held that "better off" exile children had access to their favourite toys and books, even if it put others at risk to source them: "My mom would make a real effort to get books for me; comrades [fighters in the liberation struggle] used to jump the fence with a Famous Five book for me, in the face of all the danger."138 In retrospect this respondent was "ashamed" 139 that she was treated differently.

It was evident that socio-economic status was a source of inner and interpersonal conflict for the respondents, both as children and in hindsight. For instance, a respondent was angered when his mother denied his request for Air Jordan sneakers, but soon thereafter gave the money to a needy South African family passing through Nigeria: "It was probably the most heart-sore feeling in me. How could this woman do this to me? As a child you just don't understand." 140 One respondent expressed the sense of frustration that he felt as a child because his dad was not earning an income from his political engagements: "It should pay at some point." ${ }^{\prime 41}$ On the other hand, this was also a source of pride for some children: "My dad is unemployed, but making a difference." 142

In order to assist their parents, some children exercised their agency by taking on part-time employment. Respondents spoke of completing basic administrative tasks in the ANC offices and working in the service industry. Others tried desperately to win scholarships to cover their schooling, even if it required extraordinary efforts to perform well at school.

\section{Constructions of Gender}

In some contexts, exile provided an opportunity for the reinterpretation of gender norms and values. Many respondents experienced the new wave of feminism in North America and the United Kingdom. This meant an emergence of new female role models, such as "black female astronauts, editors, and teachers." 143 Respondents described the new freedom and independence experienced by their mothers and a renegotiation of spatial public/private boundaries in North America and Europe. Many of their mothers became mobile, abandoned traditional dress, formed circles of male and female friends independently of their husbands, and entered the formal economy. This in turn led to a selective revision of domestic roles and responsibilities, with fathers cooking and plaiting their daughter's hair in Denmark, for example. ${ }^{144}$
However, exile also perpetuated gender norms and placed constraints on women's agency. As they could not rely on traditional forms of social support, including relatives or nannies, many were placed under immense pressure trying to balance employment and child care: "It was hard: there was no nanny. We had to go with her [mother] everywhere until we turned 12. In Canada a child can't be left alone in the house." 145

Children who were sent to stay in boarding schools described feelings of abandonment, although in hindsight they understood that this was the only way that their mothers could engage in paid employment. Others resented being forced to take responsibility for the care of younger siblings so that their mothers could work: "I would always tell her [mother], 'This is unfair. I feel like I have been brought here [United States] to be a maid.' I mean, I took care of my brother. With all of this happening, I was not a child."146

Many female respondents referred to the new freedom that they experienced in exile in terms of their movement, relationships, and life opportunities. However, in certain contexts, restrictions were placed on girls' political agency on the grounds of protection. Two female respondents wanted to join the Umkhonto we Sizwe (MK) and felt that if they had been boys, this would have been an option for them: "It was a gendered experience for me. I felt if I had been a boy I would have been taken more seriously."147

\section{Sexuality and Violence}

In some contexts, femininity was associated with victimization in the face of sexual and gender-based violence. Intimate partner violence, sexual harassment, and rape were experienced by women in their families. Sexual and gender-based violence in closed-off exile communities such as Morogoro was perceived as "normal" and questioned by the respondents only upon their return to South Africa. For instance, one respondent stated, "I was raped five or six times continuously. It was not disguised. For us kids it was normal. I knew that if I was coming out of that room at the day care centre with a chocolate, the next person going into that room was experiencing the same thing and it was just that ... As a kid when you are made to believe that what's happening to you is correct, you get sad only when you are older." 148

Many respondents voiced the opinion that the needs of the "movement" were placed above the needs of girls and women. For instance, a respondent spoke of being raped repeatedly by the teenage son of her parent's political friends when in exile. Although she exercised her agency by telling her parents, there was still an obligation on her parents to take the boy shopping for new clothes: "That messed me up a little. A lot of this sexual abuse stuff was rife. You were sexually molested by a comrade's child or a comrade 
themselves. There again, in South Africa that has become part of our heritage, it has been normalized by society." 149

The material realities of exile sometimes shaped constructions of sexuality around transactional relationships. One respondent spoke at length about her mother's relationships with powerful men in the exile community: "It was one of those relationships that my mom was in to make her life easier in exile. He was influential, and she did it to survive." 150

A respondent described her attempts to exercise agency in this context. She saw this abuse in transactional terms, which she could then use to assist her sibling: "As I was getting older and he was rewarding me with biscuits, the strange thing was in my mind I was saying, 'Let's allow this thing to happen, if I can take food and biscuits for my younger sister."'151 She also spoke of trying to discourage her mother from transactional sex: "I thought it was my responsibility to protect my mother. Like maybe when he is walking away, I would throw stones at them." 152 She exercised her agency by trying to defend her mother and threaten the perpetrators.

Another female respondent complained to her father about the abuse experienced by her peers, thereby exercising her agency by proxy. Other respondents referred to their participation in feminist movements in North America and Europe in their attempts to challenge norms that supported discrimination and violence against women. Some even used poetry and music to advocate for these changes in their schools and other community spaces.

\section{Conclusion}

Exile tends to be viewed narrowly as a strategic space characterized by top-down military operations, at the exclusion of everyday power struggles and interpersonal acts of resistance. Furthermore, literature describes children as a homogenous category of invisible actors, silent bystanders, or passive targets of political socialization, without considering their perspectives, decisions, and agentic behaviour when seeking refuge. This article has argued that the interplay of structure and agency in the lives of second-generation exiles should be explored.

Difference should be considered in the manner in which childhood-as intersected with socially constructed divisions such as gender, ethnicity, and socio-economic statuswas constructed and experienced by different children, living in different families in different exile communities. This article has described the constraints-and opportunitiesplaced by these social structures on children's lived realities. Moreover, it has shown how these structures have influenced interpersonal relationships, which in turn have had a significant impact on respondents' agency in exile. It has been argued that some second-generation exiles (re)interpreted, questioned, challenged, and resisted the manner in which power was distributed by acting with intentionality in certain situations, even though they felt constrained and subjugated in others.

It is impossible to make generalizations about the extent or nature of their agentic action, but these respondents have provided insight into the complex interplay of structure and agency in exile. Children responded in different ways to these structures and, in so doing, revealed forms of agency, which have heretofore been left unexamined. Many children waged struggles for freedom within their homes, fighting against what they perceived as unjust treatment. Many questioned their parents' decisions, actions, and ideologies. In their schools and communities, many fought against injustice, racism, and sexism. Some children devised strategies to exercise their agency by proxy or collectively with peers and other adults. Alternatively, they drew on inner resources when trying to manage loss, isolation, secrecy, and disruption.

As the first article emerging from this exploratory study, there are numerous gaps, contradictions, and tensions that have yet to be explored. For instance, the issue of identity has not been adequately discussed, nor has the respondents' experiences in post-apartheid South Africa, and how this has shaped their narration of exile. These issues will be discussed in subsequent publications.

At a theoretical and methodological level, the construction and reconstruction of memory will need to be further considered. Memories do not necessarily provide an "authentic" view of the past, because they are socially constructed and therefore change in relation to the vagaries of time, fluctuating dominant narratives, ideological partialities, and shifting positionality in past and present. The quotes provided in this article have revealed the tension between memories of childhood as selectively narrated and/or constructed by adults, and adult reflections of childhood made in hindsight. These tensions should be carefully unpacked in future studies that explore historical topics and utilize the life history narrative approach.

Twenty years ago the liberation struggle culminated in South Africa's first democratic elections. This "anniversary" has spurned a new wave of reflection about the realization of the liberation struggle's goals and expectations, in relation to the realities of post-apartheid South Africa. It has also reignited discussion on the silencing of voices by apartheid and the dominant narrative of the struggle in post-apartheid South Africa. This article is, therefore, timely in that it offers a unique perspective on exile as experienced by marginalized children, many of whom are now disappointed youth in a troubled South Africa. 
Furthermore, despite the plethora of progressive legislation in South Africa promoting the protection of children's rights, regardless of nationality, undocumented child migrants are subject to numerous human rights violations associated with inequitable access to quality services, structural and interpersonal violence, discrimination, and xenophobia. ${ }^{153}$ Many of these problems were experienced by children in exile during apartheid. This study will, therefore, contribute to the theoretical and empirical knowledge on children seeking refuge.

\section{Notes}

1. Michel Foucault, “The Subject and Power," Critical Inquiry 8, no. 4 (1982): 777-95.

2. Jacklyn Cock, Colonels and Cadres: War and Gender in South Africa (Cape Town: Oxford University Press, 1991); Lauretta Ngcobo, Prodigal Daughters (Durban: University of KwaZulu-Natal Press, 2012); Shireen Hassim, Women's Organisations and Democracy in South Africa: Contesting Authority (Durban: University of KwaZulu-Natal Press, 2006).

3. Albert Bandura, "Social Cognitive Theory: An Agentic Perspective," Annual Review of Psychology 52 (2001): 1-26.

4. Anthony Giddens, The Constitution of Society: Outline of the Theory of Structuration (Cambridge: Polity, 1984).

5. Edward W. Said, Reflections on Exile and Other Essays (Cambridge, MA: Harvard University Press, 2000), 181.

6. Kenneth Parker, "Home is where the heart ... lies," Transition 59 (1993): 77.

7. James Clifford, "Diasporas," Cultural Anthropology 9, no. 3 (1994): 302-38; Avtar Brah, Cartographies of Diaspora: Contesting Identities (London: Routledge, 1996).

8. Clifford, Diasporas, 307.

9. Raymond Suttner, "Culture(s) of the African National Congress of South Africa: Imprint of Exile Experiences,' Journal of Contemporary African Studies 21, no. 2 (2003): 317.

10. Arianna Lissoni and Maria Suriano, "Married to the ANC: Tanzanian Women's Entanglement in South Africa's Liberation Struggle." Unpublished, 2013, 2.

11. Foucault, "Subject and Power," 794.

12. Ngcobo, Prodigal Daughters; Cock, Colonels.

13. Lissoni and Suriano, "Married to the ANC."

14. Carla Tsampiras, "Sex in a Time of Exile: An Examination of Sexual Health, AIDS, Gender, and the ANC, 1980-1990," South African Historical Journal 64, no. 3 (2012): 637-63.

15. Hilda Bernstein, The Rift: The Exile Experience of South Africans (London: Jonathan Cape, 1994).

16. Mark Israel, South African Political Exile in the United Kingdom (New York: St. Martin's, 1999); Nadja Manghezi, The Maputo Connection (Auckland Park, Johannesburg: Jacana Media, 1991).
17. Christian A. Williams, "Living in Exile: Daily Life and International Relations at SWAPO's Kongwa Camp," Kronos 37 (2011): 60-86.

18. David Archard, Children: Rights and Childhood (London: Routledge, 1993).

19. Kimberle W. Crenshaw, "Mapping the Margins: Intersectionality, Identity Politics and Violence against Women of Color," Stanford Law Review 43, no. 6 (1991): 1241-99. Nira Yuval-Davis, "Intersectionality and Feminist Politics," European Journal of Women's Studies 13 (2006): 193-209.

20. Clifford, Diaspora, 302-38.

21. Bernstein, Rift; Manghezi, Maputo Connection.

22. The ANC's Solomon Mahlangu Freedom College was an educational institution established between 1978 and 1992 in Tanzania on land provided by the Tanzanian government. It included facilities for primary, secondary, nursery, and vocational education (Morrow, Education in Exile).

23. Morrow, Education in Exile.

24. Israel, South African Political Exile; Bernstein, Rift.

25. Bernstein, Rift.

26. Ngcobo, Prodigal Daughters.

27. This term refers to countries bordering South Africa such as Mozambique, Lesotho, and Swaziland. Manghezi, Maputo Connection; Hassim, Women's Organisations.

28. Morrow, Education in Exile; Lissoni and Suriano, "Married to the ANC."

29. Israel, South African Political Exile; Bernstein, Rift.

30. Said, Reflections on Exile, 184.

31. Clifford, Diasporas, 313.

32. Marianne Hirsch, "Past Lives: Postmemories in Exile," in Exile and Creativity: Signposts, Travellers, Outsiders, Backward Glances, ed. S.R Suleiman (Durham, NC: Duke University Press, 1998), 420.

33. Anne-Marie Fortier, Migrant Belongings: Memory, Space, Identity (Oxford: Berg, 2000).

34. Paul Allatson and Jo McCormack, "Introduction," in Exile Cultures, Misplaced Identities, ed. P. Allatson and J. McCormack, 9-33 (Amsterdam: Rodopi, 2008).

35. Ibid.

36. Jeremy Seekings, Heroes or Villains? Youth Politics in the 1980s (Braamfontein: Ravan, 1993); V. Brittain and A. S. Minty, Children of the Resistance: Statements from the Harare Conference on Children, Repression and the Law in Apartheid South Africa (London: Kliptown Books, 1998); Stephen Ellis and Tsepho Sechaba, Comrades against Apartheid: The ANC and South African Communist Party in Exile (London: James Currey, 1992); James Ngculu, The Honour to Serve: Recollections of an Umkhonto Soldier (Claremont: David Philip, 2010).

37. Bernstein, Rift, 435.

38. Sean Morrow, Brown Maaba, and Loyiso Pulumani, Education in Exile, SOMAFCO: The ANC School in Tanzania 1978-1992 (Cape Town: HSRC, 2004); Hassim, Women's Organisations.

39. Manghezi, Maputo Connection; Bernstein, Rift. 
40. Bernstein, Rift, xxiii. Gillian Slovo, Every Secret Thing: My Family, My Country (London: Little Brown, 1997).

41. Suttner, Culture of ANC.

42. Bernstein, Rift; Ngcobo, Prodigal Daughters; Cock, Colonels; Manghezi, Maputo Connection.

43. Ngcobo, Prodigal Daughters.

44. Morrow, Education in Exile; Manghezi, Maputo Connection.

45. Ngcobo, Prodigal daughters.

46. Ibid., 43.

47. James C. Scott, Weapons of the Weak: Everyday Forms of Peasant Resistance (New Haven, CT: Yale University Press, 1985): xvi.

48. Giddens, Constitution of Society.

49. Pierre Bourdieu, The Logic of Practice (London: Polity, 1990).

50. Giddens, Constitution of Society.

51. Urie Bronfenbrenner, The Ecology of Human Development: Experiments by Nature and Design (Cambridge, MA: Harvard University Press, 1979); Rom Harre, "The Step to Social Constructionism," in Children of Social Worlds: Development in a Social Context, ed. M. Richards and P. Light, 287-96 (London: Polity, 1986).

52. Foucault, "Subject and the Power," 780.

53. Bandura, Social Cognitive Theory, 3.

54. Mats Utas, "Agency of Victims: Young Women in the Liberian Civil War," in Makers and Breakers: Children and Youth in Postcolonial Africa, ed. A. Honwana and F. De Boeck, 53-80 (Oxford: Africa World Press, 2005); Jo Boyden, "Children's Experience of Conflict-Related Emergencies: Some Implications for Relief Policy and Practice," Disasters 18, no. 3 (1994): 263.

55. Foucault, "Subject and Power," 794.

56. Harre, Step to Social Constructionism.

57. Jenny Kitzinger, "Who Are You Kidding? Children, Power and the Struggle against Sexual Abuse," in Constructing and Reconstructing Childhood: Contemporary Issues in the Sociological Study of Childhood, ed. A. James and A. Prout, 165-89 (London: Falmer, 1997).

58. Rowland Atkinson and John Flint, "Accessing Hidden and Hard-to-Reach Populations: Snowballing Research Strategies," Social Research Update 33 (2001): 1-4.

59. Lisa Maher, Sexed Work: Gender, Race and Resistance in a Brooklyn Drug Market (Oxford: Clarendon, 1997), 29.

60. Anselm Straus and Juliet Corbin, Basics of Qualitative Research: Grounded Theory Procedures and Techniques (Newbury Park, CA: Sage, 1990).

61. James Clifford, "Partial Truths," in Writing Culture: The Poetics and Politics of Ethnography, ed. J. Clifford and G. E. Marcus, 91-6 (Berkeley: University of California Press, 1986); Martin Hammersley, "Some Reflections on Ethnography and Validity," Qualitative Studies in Education 5, no. 3 (1991): 195-203.

62. Philippe Denis and Radikobo Ntsimane, Oral History in a Wounded Country: Interactive Interviewing in South Africa
(Pietermaritzburg: University of KwaZulu Natal Press, 2008).

63. Julia Wells, "Are We Nation-building Yet? The Role of Oral Historians in Documenting the Transition out of Apartheid," in Denis and Ntsimane, Oral History, 33.

64. Philippe Denis, "The Ethics of Oral History," in Denis and Ntsimane, Oral History, 77.

65. The countries in which the respondents lived are Botswana, Bulgaria, Canada, Denmark, Kenya, Lesotho, Mozambique, Namibia, Nigeria, Northern Ireland, Spain, Swaziland, Tanzania, United Kingdom, United States, Zambia, and Zimbabwe.

66. Barnett F. Baron, "Southern African Student Exiles in the United States," Journal of Modern African Studies 10, no. 1 (1972): 73-91. Christian, "Living in Exile," describes these persons as "refugee students" who used educational opportunities to seek refuge.

67. Devleena Ghosh, "Coda: Eleven Stars over the Last Moments of Andalusia," in Critical Studies, Exile Cultures, Misplaced Identities (Amsterdam: Rodopi, 2008), 284.

68. Andre Brink, "Stories of History: Reimagining the Past in Post-Apartheid Narrative," in Negotiating the Past: The Making of Memory in South Africa, ed. S. Nuttall and C. Coetzee, 29-42 (Oxford: Oxford University Press, 2000); Denis and Ntsimane, Oral History.

69. Anne-Marie Fortier, Migrant Belongings: Memory, Space, Identity (Oxford: Berg, 2000); Marcela Cornejo, "Political Exile and the Construction of Identity: A Life Stories Approach," Journal of Community and Applied Social Psychology 18 (2000): 337.

70. Said, Reflections on Exile, 148.

71. Allatson and McCormack, "Introduction," 20.

72. Slovo, Every Secret Thing.

73. Said, Reflections on Exile, 140.

74. Allatson and McCormack, "Introduction," 20

75. Cornejo, "Political Exile and Construction of Identity."

76. Sarah Nuttall, "Telling 'Free' Stories? Memory and Democracy in South African Autobiography since 1994," in Nuttall and Coetzee, Negotiating the Past, 75-88.

77. Gary Minkley and Ciraj Rassool, "Orality, Memory, and Social History in South Africa" in Nuttall and Coetzee, Negotiating the Past, 90-8.

78. Njabulo Ndebele, "Memory, Metaphor and the Triumph of Narrative," in Nuttall and Coetzee, Negotiating the Past, 20.

79. Ingrid de Kok, "Cracked Heirlooms: Memory on Exhibition," in Nuttall and Coetzee, Negotiating the Past, 61.

80. Ndebele, "Memory, Metaphor and the Triumph of Narrative," 21.

81. De Kok, "Cracked Heirlooms," 62.

82. Interview, male respondent, Pretoria, 17 May 2013.

83. Interview, male respondent, Johannesburg, 28 May 2013.

84. Interview, male respondent, Pretoria, 17 May 2013.

85. Interview, female respondent, Johannesburg, 3 June 2013.

86. Interview, male respondent, Pretoria, 17 May 2013.

87. Interview, female respondent, Johannesburg, 8 June 2013. 
88. Interview, female respondent, Johannesburg, 22 May 2013.

89. Interview, male respondent, Pretoria, 17 May 2013.

90. Interview, female respondent, Johannesburg, 30 May 2013.

91. Ibid.

92. Interview, male respondent, Johannesburg, 24 May 2013.

93. Interview, male respondent, Johannesburg, 18 May 2013.

94. Interview, female respondent, Johannesburg, 6 June 2013.

95. Ibid.

96. Interview, male respondent, Pretoria, 17 May 2013.

97. Interview, female respondent, Johannesburg, 23 May 2013.

98. Interview, female respondent, Johannesburg, 3 June 2013.

99. Interview, male respondent, Johannesburg, 28 May 2013.

100. Interview, female respondent, Johannesburg, 30 May 2013. 101. Interview, female respondent, Johannesburg, 6 June 2013.

102. Interview, female respondent, Johannesburg, 30 May 2013. 103. Interview, female respondent, Johannesburg, 22 May 2013.

104. On 16 June 1976, students staged school boycotts in Soweto in the wake of attempts by the Department for Bantu Administration and Education to introduce Afrikaans as a medium of instruction. This was met with a violent state response, leading to the death of hundreds of children and the expansion of the school boycotts to the rest of South Africa involving approximately 20,000 students (Ellis and Sechaba, Comrades against Apartheid).

105. Interview, female respondent, Pretoria, 9 June 2013.

106. Interview, female respondent, Grahamstown, 4 June 2013.

107. Interview, male respondent, Johannesburg, 2 June 2013.

108. Interview, female respondent, Johannesburg, 22 May 2013. 109. Interview, female respondent, Johannesburg, 30 May 2013. 110. Interview, male respondent, Johannesburg, 2 June 2013.

111. Interview, male respondent, Johannesburg, 28 May 2013.

112. Interview, female respondent, Johannesburg, 3 June 2013.

113. Interview, female respondent, Johannesburg, 30 May 2013.

114. Interview, male respondent, Johannesburg, 28 May 2013.

115. Interview, male respondent, Johannesburg, 28 May 2013.

116. Interview, male respondent, Johannesburg, 28 May 2013.

117. Interview, male respondent, Pretoria, 17 May 2013.

118. Interview, female respondent, Johannesburg, 22 May 2013.

119. Interview, female respondent, Johannesburg, 24 May 2013.

120. Interview, female respondent, Johannesburg, 22 May 2013.

121. Ibid.

122. Interview, female respondent, Johannesburg, 23 May 2013.

123. Ibid.

124. Interview, male respondent, Pretoria, 17 May 2013.

125. Interview, female respondent, Johannesburg, 24 May 2013.

126. Interview, female respondent, Johannesburg, 6 June 2013.

127. Interview, male respondent,Johannesburg, 2 June 2013.

128. Interview, male respondent, Johannesburg, 24 May 2013.

129. Interview, female respondent, Johannesburg, 22 May 2013.

130. Interview, female respondent, Johannesburg, 23 May 2013.

131. Interview, female respondent, Pretoria, 9 June 2013.

132. Interview, female respondent, Johannesburg, 7 August 2013.

133. Interview, female respondent, Johannesburg, 22 May 2013. 134. Interview, female respondent, Johannesburg, 3 June 2013.
135. Interview, female respondent, Johannesburg, 3 June 2013. 136. Interview, female respondent, Johannesburg, 9 June 2013. 137. Interview, female respondent, Grahamstown, 4 June 2013. 138. Interview, female respondent, Johannesburg, 6 June 2013. 139. Interview, female respondent, Johannesburg, 6 June 2013. 140. Interview, male respondent, Johannesburg, 28 May 2013. 141. Interview, male respondent, Johannesburg, 23 May 2013. 142. Interview, male respondent, Johannesburg, 28 May 2013. 143. Interview, female respondent, Johannesburg, 22 May 2013. 144. Interview, female respondent, Pretoria, 9 June 2013.

145. Interview, female respondent, Johannesburg, 3 June 2013. 146. Interview, female respondent, Johannesburg, 12 June 2013. 147. Interview, female respondent, Johannesburg, 22 May 2013. 148. Interview, female respondent, Johannesburg, 23 June 2013. 149. Interview, female respondent, Grahamstown, 4 June 2013. 150. Interview, female respondent, Johannesburg, 23 June 2013. 151. Interview, female respondent, Johannesburg, 23 July 2013. 152. Ibid.

153. Ingrid Palmary, For Better Implementation of Migrant Children's Rights in South Africa (Pretoria: UNICEF, 2009).

Zosa Olenka De Sas Kropiwnicki is a senior lecturer in development studies at the University of Johannesburg. The authormay be contacted at zosag@uj.ac.za.

(C) Zosa Olenka De Sas Kropiwnicki, 2014. This open-access work is licensed under a Creative Commons Attribution-NonCommercial 4.0 International License, which permits use, reproduction and distribution in any medium for non-commercial purposes, provided the original author(s) are credited and the original publication in Refuge: Canada's Journal on Refugees is cited. 